\title{
Sedimentology and Stratigraphy of Phu Sung Fossil Site of the Lower Cretaceous Sao Khua Formation, Sakon Nakhon Province, Northeastern Thailand
}

\author{
Pitaksit Ditbanjong1* ${ }^{*}$ Phornphen Chanthasit ${ }^{2}$, Kamonlak Wongko³ \\ ${ }^{1}$ Department of Geological Sciences, Faculty of Science, Chiang Mai University, Chiang Mai, Thailand \\ ${ }^{2}$ Sirindhorn Museum, Department of Mineral Resources, Sahatsakhan, Kalasin, Thailand \\ ${ }^{3}$ Phu Wiang Fossil Research Center and Dinosaur Museum, Department of Mineral Resources, Khon Kaen, Thailand \\ Email: *pitaksit.d@cmu.ac.th
}

How to cite this paper: Ditbanjong, P., Chanthasit, P. and Wongko, K. (2019) Sedimentology and Stratigraphy of Phu Sung Fossil Site of the Lower Cretaceous Sao Khua Formation, Sakon Nakhon Province, Northeastern Thailand. Open Journal of Geology, 9, 684-687.

https://doi.org/10.4236/ojg.2019.910075

Received: August 17, 2019

Accepted: September 22, 2019

Published: September 25, 2019

Copyright $\odot 2019$ by author(s) and Scientific Research Publishing Inc. This work is licensed under the Creative Commons Attribution International License (CC BY 4.0).

http://creativecommons.org/licenses/by/4.0/

\begin{abstract}
"Phu Sung", a new fossil site in Sakon Nakhon Province was recently reported. Phu Sung fossils are very complete and in very well-preserved condition. They were found in reddish micaceous silty mudstone. The stratigraphy and sedimentology show that Phu Sung succession is a continental deposit in the fluvial system and it is in the Early Cretaceous Sao Khua Formation of the Khorat Group. According to lithology, fossils were deposited in a quiet environment, such as overbank deposit, small pond or oxbow lake margin. Sedimentary structures such as desiccation crack and calcrete indicate semi-arid to arid paleoclimate condition which probably corresponds to the taphonomy or preservation of the fossils.
\end{abstract}

\section{Keywords}

Fluvial Deposits, Sao Khua Formation, Lower Cretaceous, Northeastern Thailand

\section{Introduction}

The Khorat Group is the Mesozoic non-marine deposit. It is dominated by reddish classic sedimentary rocks including mudstone, siltstone, sandstone and conglomerate [1]. The Lower Cretaceous Sao Khua Formation of the Khorat Group is well exposed in northeastern Thailand (Figure 1) and has yielded various vertebrate remains. Stratigraphy and palynology indicate that the Sao Khua Formation is Early Cretaceous in age (Barremian) [2] [3]. Some Sao Khua 


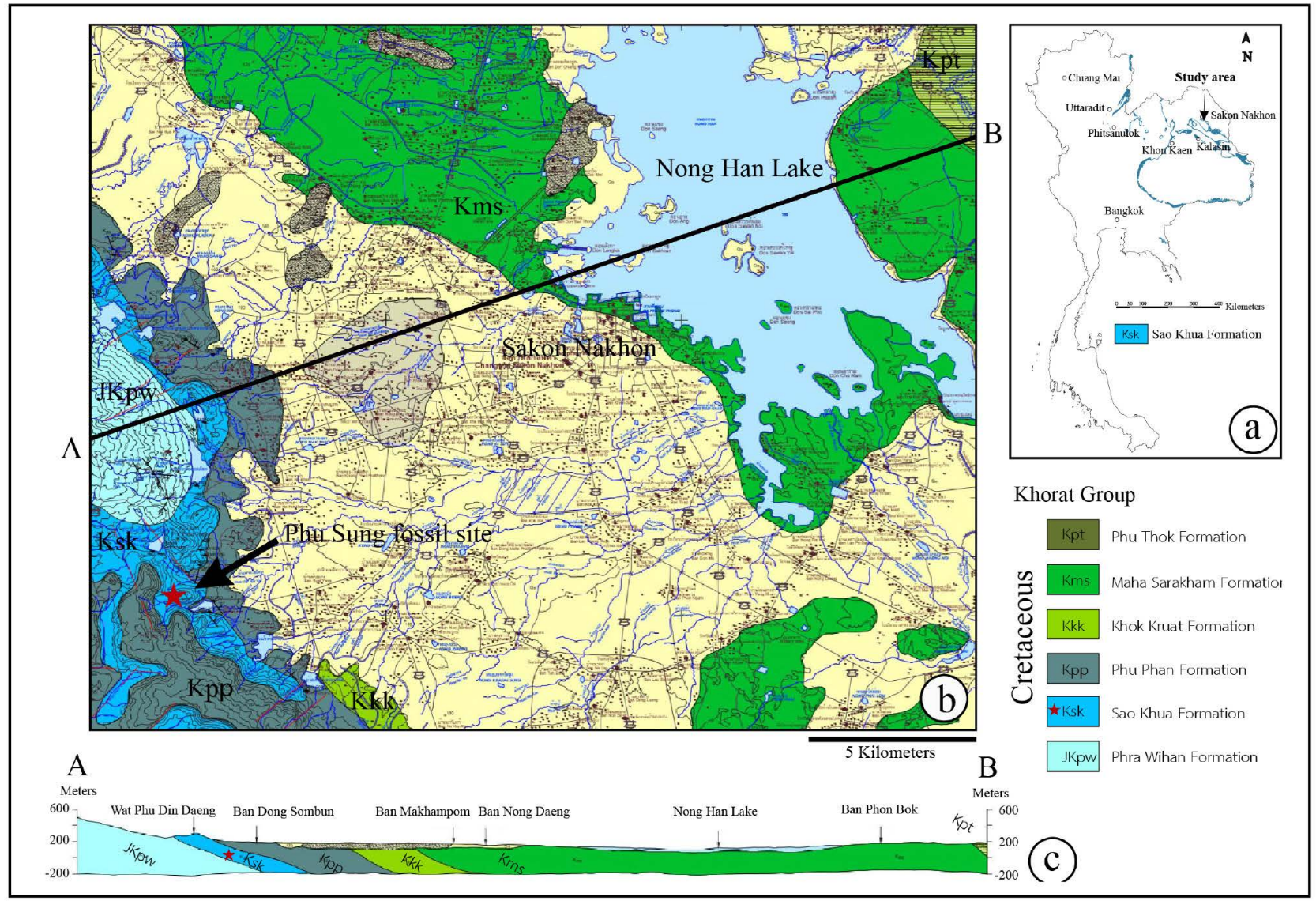

Figure 1. Study area, (a) distribution of the Lower Cretaceous Sao Khua Formation (Ksk), (b) the Phu Sung fossil site, showing in red star and (c) the cross section (line A-B) shows Ksk is underlain by white quartzitic sandstone of Kpw and it is overlain by the sandstone dominated Kpp (Modified from [4]).

vertebrate fossil sites in Sakon Nakon were previously revealed, however, most of the fossils such as fresh water shark, bony fish, turtles, crocodiles, pterosaurs, dinosaurs and lizard eggs were fragmentary. Most recently, a new vertebrate fossil site "Phu Sung" with a good fossil preservation was found near Muang Sakon Nakhon District, Sakon Nakhon Province (Figure 1). In this work, we are interested in the sedimentology and stratigraphy of the site to interpret the paleoenvironment of the Phu Sung fossil site.

\section{Sedimentology and Stratigraphy}

The Phu Sung section is more than 80 meters thick, dominated by reddish micaceous siltstone/mudstone, calcrete horizon and intercalation with sandstone and conglomerate (Figure 2). In general, sedimentary strata is NNW-SSE striking $\left(330^{\circ}-355^{\circ}\right)$ with gentle dipping $\left(5^{\circ}-10^{\circ}\right)$ to NE direction. Although outcrops are not very well exposed, the section seems to be complete and continuous. The Phu Sung section can subdivided into 3 main parts. 1) The lower part ( $\log 1)$ consists of medium- to thick-bedded sandstone with cross bedding. Sandstones are thinning upward and passing to siltstone dominated at the top. Some individual sandstone bed shows sharp erosive base with mud clast at the 


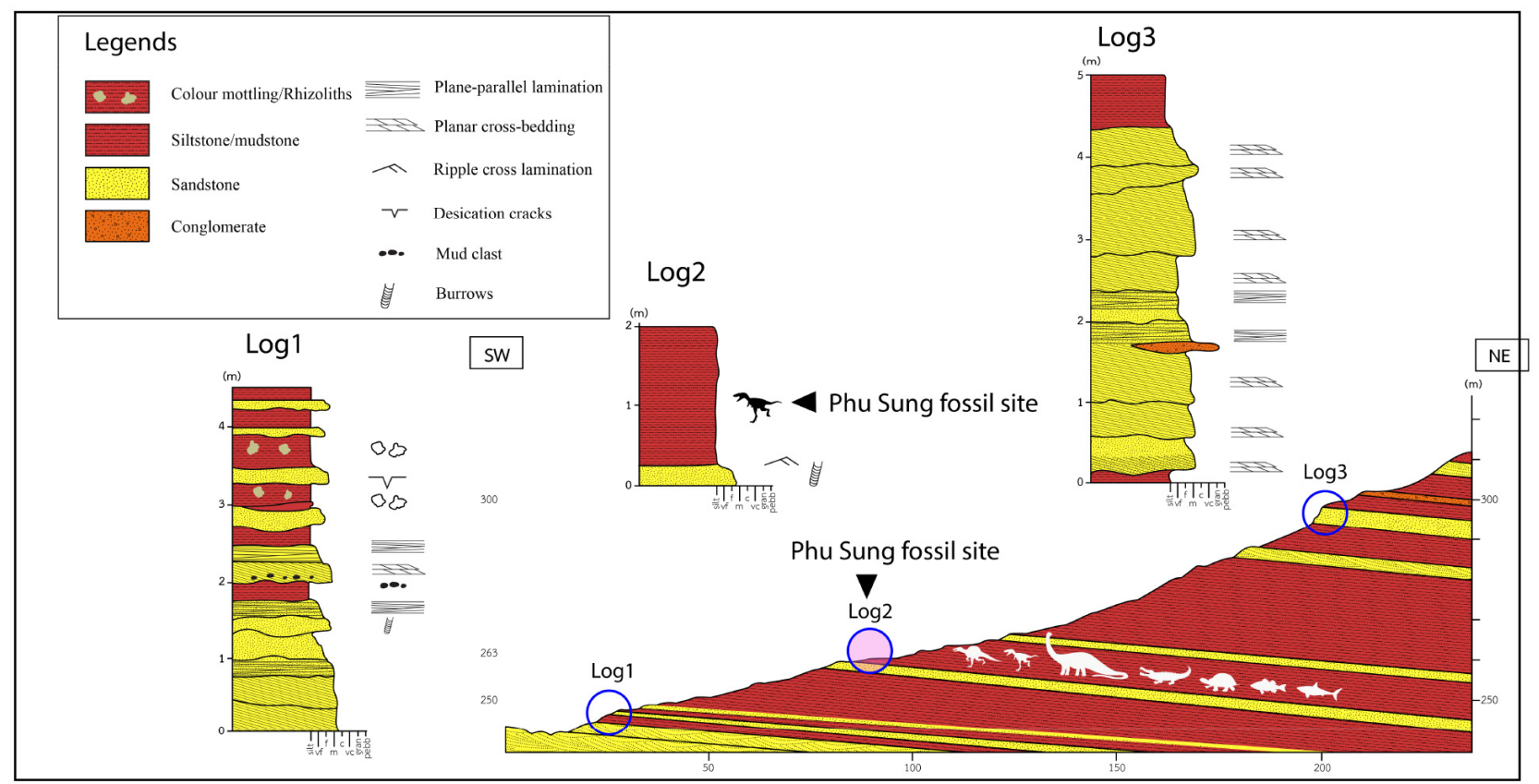

Figure 2. Geological cross section with NE-SW direction and sedimentary logs of the Phu Sung fossil site.

bottom. Vertical bioturbation and desiccation crack can be found. Reddish micaceous siltstone/mudstone with greenish grey to pale grey mottling and rhizoliths present at the top of section. 2) The middle part of the section ( $\log 2)$, where fossils were found, starts with thin to medium bedded fine-grained sandstone. It is overlain by reddish micaceous siltstone/mudstone. Calcrete nodules are commonly found on recent erosional surface. About 1 meter above a sandstone bed, fossils were found in reddish siltstone. Stratigraphically, fossil-bearing bed is situated approximately $80-100$ meters below quartzitic sandstone and conglomerate of the Phu Phan Formation. 3) The upper part (Log3) forms as a small cliff of medium- to thick-bedded sandstone. Cross-bedding and planar bedding are commonly found within sandstone. Some lenticular conglomerates present at the base of sandstone. This cross-bedding sandstone is capped atop by reddish siltstone, calcrete horizon and lime-nodule conglomeratic layer. Medium to thick bedded with cross bedding sandstone sets from the lower and the upper part of the Phu Sung succession is interpreted as main channel-filled with high energy environments. While the middle part, where fossils were found in reddish micaceous silty mudstone, is interpreted as overbank deposit swith low energy environments.

\section{Conclusion}

The Phu Sung succession is a continental deposit in the fluvial system. Fossils were found in reddish silty mudstone, indicating low energy quiet environment (overbank, small pond or oxbow lake margin). Sedimentary structures such as desiccation crack and calcrete indicate arid and semi-arid paleoclimate condition. The taphonomy and the extraordinary preservation of Phu Sung fossils 
could probably relate to the paleoenvironment and the paleoclimate in the Early Cretaceous.

\section{Acknowledgements}

We are thankful for all supports from staffs of the National Reserved Forest of Phu Lom Khao and Phu Peg. We express our gratitude to our institutes, CMU and DMR for the strong supports. This is a contribution to UNESCO/IUGS/IGCP 679 porject.

\section{Conflicts of Interest}

The authors declare no conflicts of interest regarding the publication of this paper.

\section{References}

[1] Ward, D.E. and Bunnag, D. (1964) Stratigraphy of the Mesozoic Khorat Group in Northeastern Thailand. No. 6. Department of Mineral Resources.

[2] Meesook, A. (2001) Jurassic-Cretaceous Environment of the Northeastern Thailand: Geological Survey Division, Department of Mineral Resources, Bangkok, 43 p.

[3] Racey, A. and Goodall, J.G. (2009) Palynology and Stratigraphy of the Mesozoic Khorat Group Red Bed Sequences from Thailand. Geological Society, London, Special Publications, 315, 69-83. https://doi.org/10.1144/SP315.6

[4] Boonkanpai, N., Yamansabedean, N. and Wongsahai, S. (2008) Geological Map of Thailand 1:50,000, F5843 3 (Sheet 5843 III), Changwat Sakon Nakhon. Department of Mineral Resources, Bangkok. 